\title{
What Do Prospective Teachers Think about Educational Gamification?
}

\author{
Murat Pektaş*, İbrahim Kepceoğlu \\ Department of Science and Mathematics Education, Faculty of Education, Kastamonu University, Kastamonu, Turkey
}

*Corresponding Author: mpektas@kastamonu.edu.tr

\section{ABSTRACT}

This case study investigated what prospective science education teachers think about the use of gamification in education. 44 preservice science teachers were asked to provide their opinions about the use of gamification in education after a 4-week implementation of gamification. The participants revealed the benefits of gamification such as an increase in motivation, saving time, and preventing cheating, as well as limitations such as difficulty in classroom management and technological problems. Furthermoer, according to the participants, gamification applications could be used in the assessment of instruction. While this study was carried out with respect to the playing practices in the teacher training period, it would be beneficial to study different teaching levels and apply the practices in different courses to diversify the results.

KEY WORDS: gamification; pre-service teachers; science education

\section{INTRODUCTION}

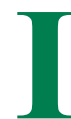
n recent years, rapid economic, social, scientific, and technological developments have changed our lifestyle. In particular, the impact of scientific and technological developments on our everyday lives is apparent. Due to the information explosion brought by the developments in science and technology and the possibilities of information technology for social and economic development, this period is called the information society (Kelly-Garrett, 2006). The information society is characterized by social life in which knowledge production and transmission are widespread, knowledge is the main capital and power, the majority of people engage in information work, and this becomes a part of the life of the learner (Marangunić and Granić, 2015). The information society is also defined as a society that allows people to access easily various presentations that concern people's lives and enable them to transform knowledge and, thus, to develop themselves (Hilbert and López, 2011).

The ways that the information society is predicted to emerge in the information age differ in terms of the methods of accessing information, and this differentiation reveals contemporary educational needs (Hamidi et al., 2011). Rapid developments in technology are driving many societies toward an informationcentered reality, and as a natural consequence, educational programs are organized in this direction. Educational policies are being reshaped from the point of view of an information society due to the increased investment in education. In this context, many developed and developing countries have been innovating to improve their education systems (Kelly-Garrett,
2006). Particularly the emphasis is on the natural cyclical relationship between science and technology. This relationship reveals the necessity of scientific research to develop new technologies, and at the same time, new technologies are also important to enable better scientific research. It is, therefore, necessary to develop individuals who think scientifically and are technologically literate.

From the beginning of the 2005/2006 academic semester, science courses in Turkey changed. Science and technology courses in the new curriculum included contemporary scientific and technological developments. The vision of these new science and technology courses was to improve science and technology literacy and to ensure that all students, regardless of their individual and cultural differences, became science and technology literate individuals (Ministry of National Education, 2015). Science and technology literacy in the new science and technology curriculum includes scientific process skills, the nature of science and technology, key science concepts, the use of mechanistic skills and technology, and constructivist thinking.

In the $21^{\text {st }}$ century, the use of multimedia (hypermedia) tools, especially computers and the Internet, necessitates the change of learning environments in educating individuals for science and technology literacy (Fraillon et al., 2014). Many research findings published in the literature (Mohammadyari and Singh, 2015; van Laar et al., 2017; Šumak and Šorgo, 2016) have led to the conclusion that the development and use of multimedia-supported instructional activities that can motivate students' visual and intellectual structures in terms of realizing 
meaningful learning have increased student success. In this point, both the learning cycle approach and multimedia tools are used in the educational environments. These are different modes of implementation of the constructivist learning theory as well as active learning, interaction, and self-learning in other learning theories (Tam, 2000; Karagiorgi and Symeou, 2005). The developments in computer and internet technologies, in particular, have dramatically increased the methods used in the teaching-learning process and trainers have developed new teaching-learning models using multimedia tools ( $\mathrm{Su}$ et al., 2005).

The influence of the "information era" and the quest for innovation and quality in education lead to the integration of new technological tools and practices. One of the popular terms in education is "gamification." In the literature, this term has been defined differently. Deterding et al. (2011) defined gamification as the use of game design elements in non-game contexts. EduTrends (2016) defined it as the application of game principles and elements in a learning environment to influence students' behavior, increase their motivation, and drive participation. Zichermann and Cunnigham (2011) defined gamification as the process of game-thinking and game mechanics to engage users and solve problems. According to these definitions, four components characterize the gamification concept: Game elements, design, context, and player.

Table 1 lists the game elements that have the potential to be used in educational settings according to the learning and instruction process. In the design of a gamification environment, several game elements can be used to engage learners in the instructional process. There is no obligation to use all the elements. However, for an environment to be considered a gamification context, at least one of the game elements as mentioned in Table 1 should be used in every instructional process.

Depending on the game elements used, gamification offers some benefits with several impacts in a learning situation. It is important to note that many of these benefits are based on hypotheses rather than verifications (Kim, 2015), as there are few scientific and empirical studies on gamification. However, some of the main benefits that have been identified (Bruder, 2015; Kapp, 2012; Zichermann and Cunningham, 2011) are as follows:

- It increases motivation. Students have a greater degree of involvement in the gamified activity. Game elements encourage them to keep their motivation positive to achieve new objectives. Play-based instruction is effective and useful, making it a good method by which to teach mathematics without boring or dictating to children.

- It provides a safe learning experience. A gamified learning experience encourages participants to complete new challenges without the fear of facing real-life consequences.

- It generates cooperation among students. Gamified activities foster social skills for team play, decisionmaking, and problem-solving.

- It informs students about their progress during gamified activities. The more frequent and timely the feedback, the more effective the learning is.

Gamification can be used to provide incentives for expected behaviors in education and to ensure that expected behaviors help students to reach positive learning outcomes. Moreover, gamification has many cognitive, emotional, and social benefits (Lee and Hammer, 2011). Students have the chance to improve their critical thinking skills as they could spend several hours applying them in game-based environments (Gee, 2003). Moreover, students become ready to face learning failures, since game-based environments can evoke feelings of curiosity and disappointment (Lazzaro, 2004). Different studies have demonstrated that the use of gamification in education increases motivation, learning outcomes, and active engagement in a course (Lee and Hammer, 2011; Muntean, 2011).

For technology to integrate fully into teaching, technological tools must be used as assessment tools for both formative and summative purposes. Gamification applications may be used for these purposes because, in a gamified activity, students perform actions while performing complex processes, such as problem-solving. The evidence required to assess these skills is provided by the players' interactions in the activity (Shute and Ke, 2012). In a gamified activity, the assessment must be as unintrusive as possible to keep the players engaged. This can be accomplished through what is known as stealth assessment (Shute, 2011; Shute et al., 2009). Kocadere and Çağlar (2015) found that the gamified assessment design increased enjoyment, flow, learning experience, and motivation and decreased examination anxiety. Table 2 shows how some of the game elements support assessment in gamified activities (EduTrends, 2016).

Competency-based education is a key asset for today's

\section{Table 1: Game elements in instructional processes}

\begin{tabular}{ll}
\hline Instructional process & Game elements \\
\hline Stating goals, objectives, and game rules & Challenges, missions, how to win or lose points, maintain lives, complete a mission \\
Student participation and engagement & Character, avatars, multiple lives, restart points, endless possibilities \\
Assessment, evaluation, and rewards & Virtual coins, lives, equipment, access items, limited or unlimited powers \\
Feedback & Clues, signs, progress bars, warnings \\
Cooperation/collaboration & Teams, guides, social interaction, battles, communication ways, transactions, helping others \\
\hline
\end{tabular}




\section{Table 2: How game elements support assessment}

\begin{tabular}{ll}
\hline Game elements & How do they support assessment? \\
\hline Challenges, missions & Demonstration of the capacity to apply knowledge and perform specific tasks \\
Game rules and restrictions & Demonstration of attitudes such as respect and honesty \\
Choosing different ways & Demonstration of skills such as decision-making, problem-solving, and creativity \\
Multiple lives, restart points, multiple opportunities to & Development of specific skills or knowledge mastery; demonstration of attitudes such \\
complete tasks & as resilience and tolerance for frustration \\
Teams, roles, battles & Promotion of collaborative work, problem-solving, and leadership \\
Points, levels, progress bars & Provision of information on student progress toward the attainments of goals
\end{tabular}

students to succeed in the globalized workplace based on better alignment between industry needs and classroom teaching (Strata-Etan Expert Group, 2002). Moreover, to achieve complex knowledge and develop the ability to put that knowledge into practice, the competency-based approach has emerged as a new educational paradigm (Charland et al., 2015). Literature suggests that gamification can contribute to develop higher order cognitive abilities such as problem-solving and critical thinking skills (Oblinger, 2004). Gamification represents a great potential for a competency-based education, in which the emphasis is not on the curriculum and domainspecific knowledge but is oriented to a learner-centered and outcome-based approach. More specifically, gamification facilitates assessment based on each student's needs (Hanus and Fox, 2015). Therefore, in this study, it is aimed to introduce some educational gamification tools to pre-service teachers and to enable them to experience these tools. Furthermore, after the sessions where pre-service teachers have experienced, their opinions are interrogated about gamification tools. Since pre-service teachers are seen as teachers of the future, it is important for them to know and use these tools and also it is important to reveal their opinions.

\section{Research Problem}

In this study, the main research question was: What do prospective science education teachers think when gamification applications are used as assessment tools in education? In this context, the aim of the study was to gather and analyze prospective science teachers' opinions about gamification after they experienced it themselves as students. The sub-questions of the study were as follows:

- What do participants think about gamification applications in terms of their benefits and limitations?

- In which stage of instruction do they think that gamification applications would be the most useful?

\section{METHODOLOGY}

\section{Research Design}

This paper describes case study research. In a case study, the main focus is on a contemporary phenomenon within its real-life context, and the boundaries between the phenomenon and its context are not clearly evident (Taylor et al., 2015). In this way, situations that are recognized but do not have a detailed or in-depth understanding are revealed (Holstein and Gubrium, 1996).

\section{Working Group}

The study was conducted in the education faculty of a state university in the 2016-2017 academic year. The sampling method was purposeful sampling. The main reason for choosing the working group was that they had already taken the Biology I and II courses, and the questions used in the gamification applications are about "biological systems" that were taught in these courses. Further, the working group had never experienced gamification. The working group consisted of 44 pre-service science teachers ( 25 female and 19 male) in their $3^{\text {rd }}$ year at university.

\section{Instruments}

An open-ended questionnaire and clinical interviews were used to collect the data.

\section{Open-ended questionnaire}

This questionnaire was used to collect data about the participants' opinions on the use of gamification in education. The questionnaire consists of the following three questions. These questions have been chosen after a literature review. The participants are asked to write their opinions in response.

1. What are the positive aspects and benefits of the gamification applications in the courses?

2. What are the negative aspects and limitations of the gamification applications in the courses?

3. At which stage of the courses should the gamification be used?

\section{Clinical interviews}

A semi-structured clinical interview method was chosen as the means of data collection because this method is well suited for the exploration of participants' opinions regarding complex and sometimes sensitive issues, and it enables researchers to probe for more information and clarification of answers.

The interviews were conducted with four participants (two female and two male). The participants were chosen based on their written answers to the open-ended questionnaire. Two of them (one female and one male) had more positive views than negative ones, whereas the other two had more negative views than positive ones. In the interviews, the participants were asked to elaborate on their views about the gamification applications in the educational environment. To prevent loss of data, the interviews were recorded through a voice recorder application on a smartphone. 


\section{PROCEDURE}

The implementation of the gamification applications lasted 4 weeks ( $3 \mathrm{hp} /$ week) in an elective course. The activities for each week are shown in Table 3 .

In week 1, the researchers described what gamification was, which elements a gamification-based course should include, and where gamification might be used in the instructional process. In the following weeks, three different gamification programs were used so that participants experienced gamification in an educational environment. In these periods of instruction, the participants acted as students, answering questions that the researchers prepared and uploaded in a gamification application. Figure 1 shows a question and four answer choices about the types of renals in aves.

The participants used their smartphones to answer the question within the given time. When the time was up, the smartphone informed them whether their answer was correct or not and also their rank among their classmates. All the questions in each gamification program were related to biological systems, and they were taken from Pektaş (2008). Pektaş's (2008) research determined the validity and reliability of the questions. Since these questions were part of an achievement test, KuderRichardson Formula (KR21) was applied to scores to measure reliability. The reliability coefficient was 0.763 . For the content validity of the questions, two academicians in science education and one biology teacher had revised the questions.

\section{Data Analysis}

The qualitative data collected through the open-ended questionnaires were analyzed using open coding. First, the significant statements in the open-ended questionnaire

\begin{tabular}{ll}
\hline Table 3: Gamification application design \\
\hline Session & Activity \\
\hline Week 1 & Description of gamification and game elements \\
Week 2 & Application of Kahoot \\
Week 3 & Application of Plickers \\
Week 4 & Application of FlipQuiz \\
\hline
\end{tabular}

responses were categorized, and themes were emerged. Second, lists of themes were controlled, and recurring themes were identified. Finally, the final version of the list of themes was created.

\section{FINDINGS}

In this section, the 44 pre-service teachers' opinions about the use of gamification in education are described with respect to each question in the open-ended questionnaire. Later, the opinions of the four pre-service teachers who participated in the clinical interviews are presented.

\section{Positive Aspects and Benefits of Gamification}

As shown in Table 4, the increase in students' motivation is revealed as the most significant benefit of gamification (39 participants, 88.63\%). According to these 39 participants, applications of gamification in education increase students' motivation in courses because they can be new and striking for students if they are used for the first time. Examples of the participants' written answers are shown in Figures 2 and 3.

An English translation of Figure 2 would read, "These applications led students to be more active in courses. With the help of the applications, the questions were understood better and permanently. The courses were comprehensive and entertaining."

A translation of Figure 3 would read, "The application in the course has increased the interest of the whole class, and all of us participated actively."

Similarly, as the applications were new to the participants, 22 participants $(50 \%)$ noted emotive responses, such as having fun during the games, as a benefit of gamification. According to them, in comparison with traditional instruction methods commonly used today, the applications of gamification may allow students to have more fun in classrooms (Figure 4).

Translation in English, "The applications in the course were very pleasant and entertaining. They also helped us to see different questions."

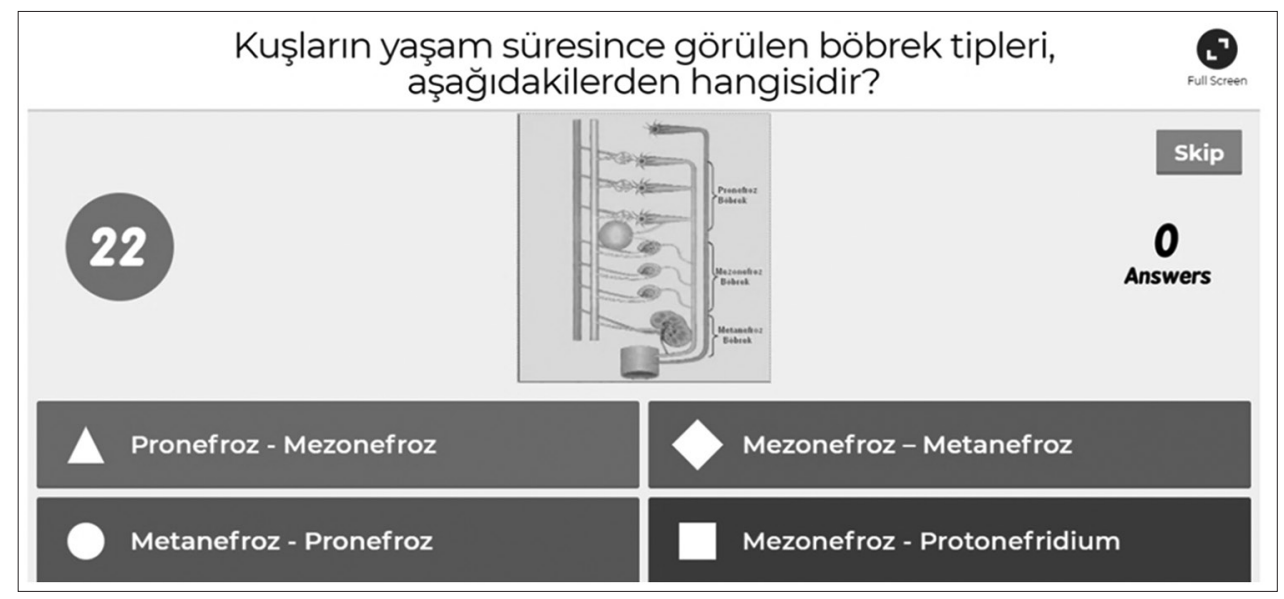

Figure 1: Example question in Kahoot1 
Furthermore, 21 of the participants (47.72\%) stated that gamification applications could help teachers to observe students' learning quickly because, using the applications, teachers can see whether students' answers were correct. Therefore, they could recognize the level of students' learning. In addition, as the gamification applications are new and striking, the scientific knowledge that students acquire from them could be retained on a longer basis (Figure 5).

In English, "When these application are used in class, students participate in the course more effectively than with the use of a test, and it becomes more entertaining. Afterward, the success rate is calculated quickly. We can see in a few seconds who has

\begin{tabular}{lc}
\hline Table 4: Benefits of gamification & \\
\hline Benefit & Frequency \\
\hline Increase of motivation & 39 \\
Being funny & 22 \\
Observation of students' learning & 21 \\
Permanence of learning & 14 \\
Time-saving & 12 \\
Collaboration in groups & 10 \\
Prevention of cheating & 7 \\
Rivalry/competition & 7 \\
Attractiveness of technology & 5 \\
Consolidation of learning & 3 \\
\hline
\end{tabular}

more wrong and more correct answers. So, time is saved. At that moment, you have to answer directly, and in every process, the student himself plays an important role. Each student takes care of himself. So, he uses practical intelligence without help, and the speed of solving questions increases. Students develop the ability to understand and recognize the environment."

The next benefit that was pointed out with high frequency (27.27\% of participants) was that gamification applications help teachers to save time in assessment since results can be obtained within a few seconds.

An interesting benefit that seven of the participants noted were that gamification applications were useful tools in helping to prevent cheating. Especially in Plickers, students used different two-dimensional (2-D) barcodes to answer a question, so they could not cheat by giving the same answers.

\section{Negative Aspects and Limitations of Gamification}

As shown in Table 5, a decrease in students' motivation was revealed as the most significant negative aspect of gamification (22 participants, $50 \%$ ). This finding seems to contradict the previous finding that the gamification applications may improve students' motivation. However, the participants who thought that gamification may lead to a decrease in motivation pointed out that, especially since students' answers were evaluated quickly, a student who gives consecutive wrong

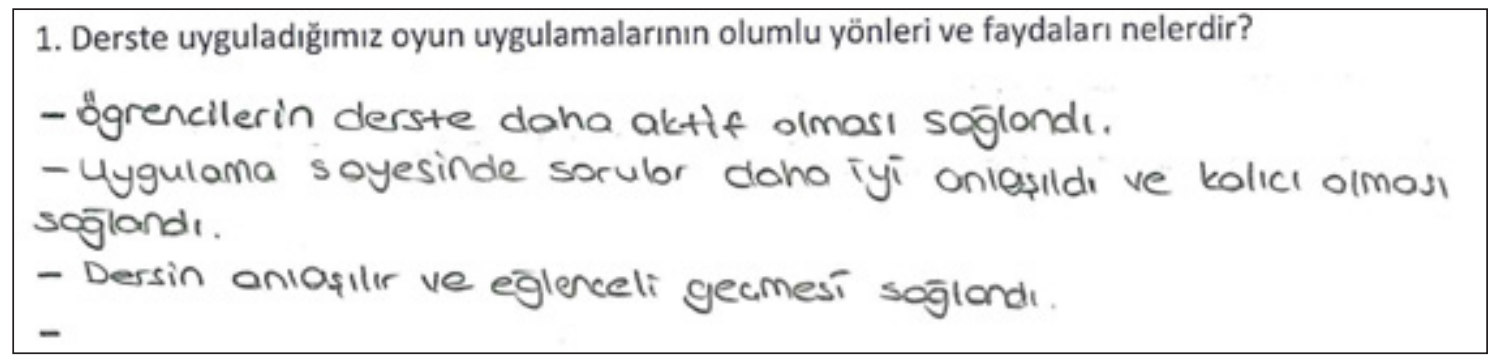

Figure 2: First example response to Question 1

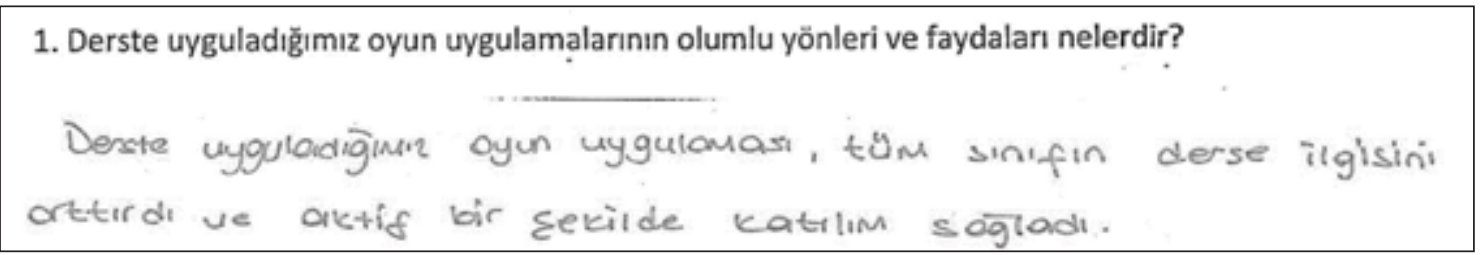

Figure 3: Second example response to Question 1

\section{Derste uyguladığımız oyun uygulamalarının olumlu yönleri ve faydaları nelerdir?}

$$
\begin{aligned}
& \text { Derste ijgulanan ofjun cok kejifli ve eglencelitydi } \\
& \text { Ögrencinin farki, soruları do görmesine yardimc, olan } \\
& \text { bir uygulamaiddi. }
\end{aligned}
$$

Figure 4: Third example response to Question 1 
answers may lose self-confidence and feel demotivated in the classroom. In addition, if students do not like the application, they can lose their motivation (example of participant's answer is shown in Figure 6).

In English, “Of course, these applications don't have only positive aspects. For example, if a student has low selfconfidence and $\mathrm{s} /$ he sees that his/her answer is wrong when other friends' ones are correct, s/he may feel uncomfortable, and therefore s/he loses his/her motivation."

"Difficulties in classroom management" was the second most frequently mentioned negative aspect (18 participants, $40.9 \%$ ). In those 18 participants' opinions, teachers may have difficulties controlling classrooms when students use the applications because teachers then must deal with technological issues.

As all gamification applications are based on some technology, possible technological problems may affect courses and instruction. This negative aspect was cited by 13 participants (29.54\%).

Furthermore, as Table 5 shows, $27.27 \%$ of the participants thought that gamification applications take too much time and

\section{Table 5: Negative aspects of gamification}

\begin{tabular}{lc}
\hline Opinion & Frequency \\
\hline Loss of motivation & 22 \\
Difficulty in classroom management & 18 \\
Technological problems & 13 \\
Waste of time & 12 \\
Limitation of time & 12 \\
Applicability & 9 \\
Posing only questions & 6 \\
Discussion among students & 6 \\
Tendency to cheat & 3 \\
\hline
\end{tabular}

affect course plans negatively or that, in some gamification applications such as Kahoot, the time limit may lead students to give wrong answers or to give answers without putting sufficient thought into their responses. Furthermore, according to some participants, gamification tools cannot be applied to every course $(20.45 \%)$ and the gamification applications only pose questions without presenting information such as lecture notes $(13.63 \%)$ (example of participant's answer is shown in Figure7).

In English, "It is difficult to use for every su bject. The time limit can be problematic for some courses."

\section{Instructional Stage of Gamification Use}

As shown in Table 6, 41 participants (93.18\%) thought that gamification applications could be used in the assessment part of instruction as summative assessment tools. In the gamification applications presented in this study, the participants chose a correct answer in a test with multiple choices. Therefore, the participants assumed that the applications may be best used to assess students' learning and to give a mark to determine students' success (example of participant's answer is shown in Figures 8 and 9).

In English, "These applications may be used at the final stage. Questions cannot be answered without giving some information about courses. After the subjects are learned, with the help of games, the knowledge may be consolidated."

In English, "These applications may be used at the assessment stage, when courses have been instructed in detail. Students have the opportunity to consolidate their learning."

Moreover, $34.09 \%$ of the participants stated that gamification applications could be used in the introduction phase of instruction to attract students' attention and motivate them (example of participant's answer is shown in Figure 10).

In English, "At the beginning of a course, these applications may be used to motivate students, to make courses more interesting and comprehensive."

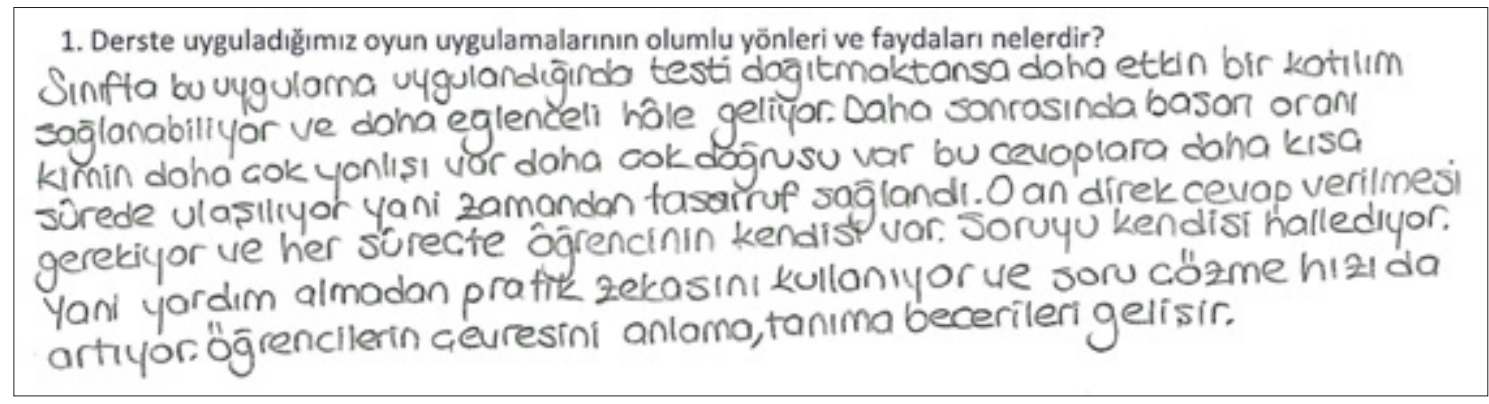

Figure 5: Fourth example response to Question

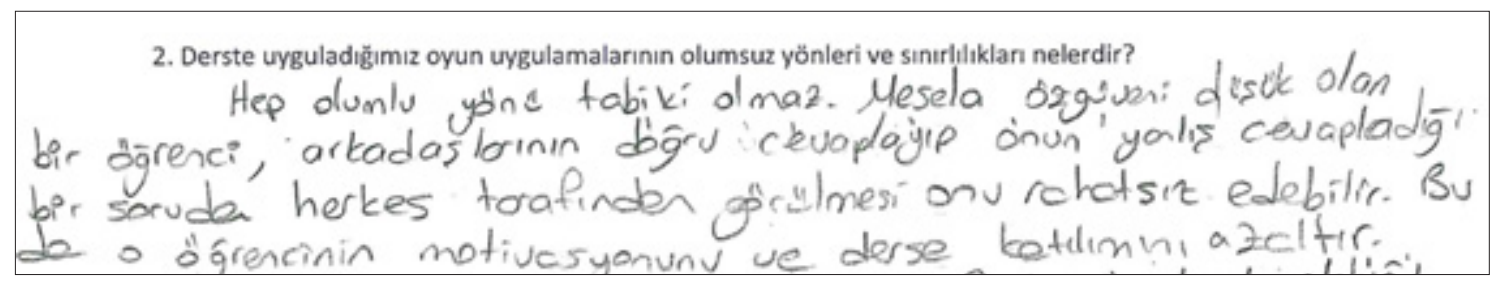

Figure 6: First example response to Question 2 
2. Derste uyguladığımız oyun uygulamalarının olumsuz yönleri ve sınırıılıları nelerdir?

- Her konutain uygularmasi zordur.

- Bazi dersler thin zoman yönüden sinirh olabilir.

Figure 7: Second example response to Question 2

3. Bu oyun uygulamaları derslerin hangi aşamalarında kullanılabilir?

Derslerin sonua asamasinda yygulanobilir. Brir bilgi verilmeden sorvlar cevaplanamayabilir. Konular ygrelildikten sonra quunla bilgiler pekiś tirilmis dur.

Figure 8: First example response to Question 3

3. Bu oyun uygulamaları derslerin hangi aşamalarında kullanılabilir?

$\rightarrow$ Ders gycintili sekilde alatilip degorlendive kismina geddiginde

bu oyun ugulandar kallaribibitis.

$\rightarrow$ Dejuladivare oluak kulkaldguds ijenci ösrendizin pokiztiv.

$\rightarrow$ Ronuler igiec örailip onda sara yapllmadi zyi dur.

Figure 9: Second example response to Question 3

3. Bu oyun uygulamaları derslerin hangi aşamalarında kullanılabilir?
- Derse basbrken
Bidulenmede,
dersin tahacol igi aetici dmar
ve antosilir hole
jelmesi
asamalorinda kullanilobilic

Figure 10: Third example response to Question 3

\begin{tabular}{lc}
\hline Table 6: Instructional stage & \\
\hline Opinion & Frequency \\
\hline Summative assessment & 41 \\
Introduction & 15 \\
Formative assessment & 4 \\
\hline
\end{tabular}

Findings from Clinical Interviews

This section presents the findings from the four clinical interviews. The participants were coded as P1, P2, P3, and P4, where $\mathrm{P} 1$ and $\mathrm{P} 2$ had more positive views about gamification and P3 and P4 had negative ones. The findings are based on the participants' responses to each question.

First, the participants were asked to choose their favorite application and explain their preference. P1 gave the following answer:
I found Plickers as the most efficient between three applications because in Kahoot, there is a time constraint to answer the questions, for example, one or two minutes, and in Flipquiz, we have to work in groups, and I don't like to work like this. But in contrast, in Plickers, I can receive quick feedback on my answers, and there is no competitive environment. We answer individually, and we see our levels of knowledge.

$\mathrm{P} 2$ responded as follows:

I prefer Flipquiz because this application requires group work, and in this way, Flipquiz lets students learn how to work in groups and to enjoy studying in class. In addition, to use Kahoot in the classroom, we need to have an internet connection. Because of this requirement, I think Kahoot cannot be used in any classrooms. 
P3 and P4 said that they had no preference among the three applications and that each application could be used in a different context.

The second question was, "What do you think of using gamification applications in instruction?" P4 gave the following answer:

Nowadays, it is inevitable to use such applications in classrooms because of the rapid development of technology. Especially, for me, it is very interesting to introduce smartphones into educational settings. But I don't find them efficient in terms of the time perspective. In addition, since using mobile phones is not allowed in schools, it would be very difficult to use Kahoot in classrooms. This is an important problem.

The other interviewees emphasized that technology illiteracy would pose a barrier to teachers' implementation of gamification applications in the classroom.

The third question was about the role of gamification applications in assessment. All four participants indicated that, using the applications, at the end of a subject or a chapter, they could determine the level of students' learning and any remaining deficiencies.

Among the four interviewees, only P3 mentioned the importance of students' readiness for the learning materials when using gamification applications. P3's response to the third question is as follows:

When Plickers or Kahoot is played before a new subject is introduced, we can see how much students know about that subject and how much they learned from previous courses. Therefore, we can determine their readiness to start a new one. Also, if students encounter more than one different stimulation, their achievement in the courses may increase. None of the participants emphasized the formative assessment perspective in discussing the implementation of the applications.

The last question asked was, "For which grade level would you consider using these applications as a pre-service teacher?" $\mathrm{P} 4$ gave the following answer:

I think that Plickers can be used in primary school classes, which are not particularly crowded. It can be difficult to prepare 2-D barcodes in crowded classrooms. I even think that it would be interesting to organize a Plickers League among elementary school students to increase their motivation.

P1 suggested the following:

Kahoot can be implemented in senior classes because of the time constraints, the need for an internet connection, and the need for a smartphone or tablet. I think that the application of Flipquiz will be more efficient in primary and middle schools where cooperative learning environments are applied more.

On the other hand, P2 responded as follows:

In our country, basic technology literacy would be needed for the implementation of such gamification applications in the classroom environment. Therefore, I think it would be more efficient to implement these applications in high school and upper classes.

P3 said:

The important factor in the basic approach to the implementation of these practices in the classroom environment is not related to the class level. Indeed, it is important whether the classroom environment has the necessary technological equipment or not.

By examining the clinical interview data, in general, we can see that these pre-service teachers had different views on the implementation of the gamification applications in the classroom environment, but they shared the view that such applications would increase students' motivation.

\section{DISCUSSION AND IMPLICATIONS}

Overall, the participants stated that they were happy to be involved in the gamification application implementation, they enjoyed it, they had an effective and lasting learning experience, they increased their success through positive competition, communication with their friends increased, their desire for work was stimulated, and their interests and motivations increased. Many studies have shown that the use of gamification in learning environments positively influences student motivation, interest, and active participation (Bell, 2014; Lee and Hammer, 2011; Measles and Abu-Dawood, 2015; Rouse, 2013; Toda et al., 2014; Wood and Reiners, 2012). Lee and Hammer (2011) suggested that gamification will support students emotionally and socially. Simões et al. (2013) stated that the social fabric of the gamification-based environment is supported by structures such as competition and cooperation. Eleftheria et al. (2013) stated that learners achieved a more comprehensive understanding of the amusement environment. Harrold (2015) determined that, with gamification, students improved their learning habits and increased their ability to solve complex problems without guidance. Hamari et al. (2014) examined 24 studies on gamification and found that gamification generally has a positive influence on student motivation, psychological outcomes, and behavioral outcomes. In this respect, it appears that the findings of this study support the above literature.

The participants talked about the lack of infrastructure and the fact that this caused competition in part due to the adverse effects of the process. If the shortcomings of the infrastructure are considered to be related to the distance education process, not the process of gamification, there is nothing remarkable as a negative element. There was no study in the literature that included negative aspects. Educational gamification can be perceived at first glance as contrary to known learning approaches. Yet it is clear that this situation is far from one where students race in contemporary learning approaches; instead, each individual is valued, and the classroom environment inspires confidence. However, the results obtained from interviews with students are a refutation of this criticism. 
In fact, these students talked about the positive competition in the course environment and the positive effects of this competition on success-motivation.

Since the students' opinions about gamification-based evaluation are generally positive, it can be integrated into the curriculum of play, which can be successfully implemented in the educational process. It is also evident that the process of education play will have positive effects on students. Since this study was carried out with respect to the playing practices in the teacher training period, it is important to study different teaching levels and apply the practices in different courses to diversify the results. In addition, the teaching process in the study was operated with distance education support. It is also important to examine the reflection of play in the teaching process in environments where there is no distance education support.

\section{REFERENCES}

Bell, K.R. (2014). Online 3.0-the Rise of the Gamer Educator the Potential Role of Gamification in Online Education (Doctoral Dissertation). Available from ProQuest Dissertations and Theses Global. (Order No. 3635727).

Bruder, P. (2015). Game on: Gamification in the classroom. The Education Digest, 80(7), 56-60.

Charland, P., Léger, P.M., Cronan, T.P., \& Robert, J. (2015). Developing and assessing ERP competencies: Basic and complex knowledge. Journal of Computer Information Systems, 56(1), 31-39.

Deterding, S., Dixon, D., Khaled, R., \& Nacke, L. (2011). From game design elements to gamefulness: Defining gamification. In: Lugmays, A., Fransilla, H., \& Hammouda, I., (Eds.), Proceedings of the $15^{\text {th }}$ International Academic MindTrek Conference: Envisioning Future Media Environments. Tampere, Finland: Association for Computing Machinery. pp. 9-15.

EduTrends. (2016). Gamification. Available from: https://www.observatorio. itesm.mx/edutrendsgamificacion. [Last Retrieved on 2018 Jul 15].

Eleftheria, C.A., Charikleia, P., Iason, C.G., Athanasios, T., \& Dimitrios, T. (2013). An innovative Augmented Reality Educational Platform Using Gamification to Enhance Lifelong Learning and Cultural Education. Paper Presented at Information, Intelligence, Systems and Applications (IISA), 2013 Fourth International Conference. Piraeus-Athens, Greece.

Fraillon, J., Ainley, J., Schulz, W., \& Friedman, T. (2014). Preparing for Life in a Digital Age: The IEA International Computer and Information Literacy Study International Report. Springer.

Gee, J.P. (2003). What video games have to teach us about learning and literacy. Computers in Entertainment, 1(1), 20-32.

Hamari, J., Koivisto, J., \& Sarsa, H. (2014). Does Gamification Work? A Literature Review of Empirical Studies on Gamification. Paper Presented at System Sciences (HICSS), 2014 47 $7^{\text {th }}$ Hawaii International Conference. Hawaii, USA.

Hamidi, F., Meshkat, M., Rezaee, M., \& Jafari, M. (2011). Information technology in education. Procedia Computer Science, 3, 369-373.

Hanus, M.D., \& Fox, J. (2015). Assessing the effects of gamification in the classroom: A longitudinal study on intrinsic motivation, social comparison, satisfaction, effort, and academic performance. Computers and Education, 80, 152-161.

Harrold, D.J. (2015). Game On: A Qualitative Case Study on the Effects of Gamified Curriculum Design on Student Motivational Learning Habits. (Doctoral Dissertation). Available from ProQuest Dissertations and Theses Global. (Order No. 3691842).

Hilbert, M., \& López, P. (2011). The world's technological capacity to store, communicate, and compute information. Science, 332(6025), 60-65.

Holstein, J.A., \& Gubrium, J.F. (1996). Phenomenology, ethnomethodology and interpretive practice: Strategies of qualitative inquiry. In: Denzin, N.K., \& Lincoln, Y.S., (Eds.), Strategies of Qualitative Inquiry.
London: Sage Publication. pp. 135-157.

Kapp, K. (2012). Games, gamification, and the quest for learner engagement. T and $D, 66(6), 64-68$

Karagiorgi, Y., \& Symeou, L. (2005). Translating constructivism into instructional design: Potential and limitations. Educational Technology and Society, 8(1), 17-27.

Kelly-Garrett, R. (2006). Protest in an information society: A review of literature on social movements and new ICTs. Information, Communication and Society, 9(2), 202-224.

Kim, B. (2015). Understanding gamification. Library Technology Reports, 51(2), 29-35.

Kocadere, S.A., \& Çağlar, Ş. (2015). The design and implement of a gamified assessment. Journal of E-Learning and Knowledge Society, 11(3), 85-99.

Lazzaro, N. (2004). Why We Play Games: Four Keys to More Emotion Without Story. Available from: https://www.files.nyu.edu/fm9/public/ Downloads/11/xeodesign_whyweplaygames.pdf. [Last Retrieved on 2018 Jul 14].

Lee, J.J., \& Hammer, J. (2011). Gamification in education: What, how, why bother? Academic Exchange Quarterly, 15(2), 146.

Marangunić, N., \& Granić, A. (2015). Technology acceptance model: A literature review from 1986 to 2013. Universal Access in the Information Society, 14(1), 81-95.

Measles, S., \& Abu-Dawood, S. (2015). Gamification: Game-Based Methods and Strategies to Increase Engagement and Motivation Within an E-Learning Environment. Paper Presented at Society for Information Technology and Teacher Education International Conference. Austin, TX.

Ministry of National Education. (2015). Ortaokul Fen ve Teknoloji Dersi Ögretim Programı [Elementary Science and Technology Course Curriculum]. Ankara, Turkey: Ministry of National Education.

Mohammadyari, S., \& Singh, H. (2015). Understanding the effect of e-learning on individual performance: The role of digital literacy. Computers and Education, 82, 11-25.

Muntean, C.I. (2011). Raising Engagement in E-Learning Through Gamification. Paper Presented at $6^{\text {th }}$ International Conference on Virtual Learning. Cluj, Romania.

Oblinger, D.G. (2004). The next generation of educational engagement. Journal of Interactive Media in Education, 8(1), 1-18.

Pektaş, M. (2008). Biyoloji Öğretiminde Yapılandırmacı Yaklaşımın ve Bilgisayar Destekli Öğretimin Öğrenci Başarlsı ve Tutumlarına Etkisi. [The Influence of Constructivist Approach and Computer Assisted Instruction in Biology Teaching on the Students' Achievements and Attitudes]. (Unpublished Doctoral Dissertation, Gazi University Institute of Educational Sciences, Ankara, Turkey).

Rouse, K.E. (2013). Gamification in Science Education: The Relationship of Educational Games to Motivation and Achievement (Doctoral Dissertation). Available from ProQuest Dissertations and Theses Global. (Order No. 3569748)

Shute, V. (2011). Stealth assessment in computer-based games to support learning. Computer Games and Instruction, 55(2), 503-524.

Shute, V., \& Ke, F. (2012). Games, learning and assessment. In: EIfenthaler, D., (Ed.), Assessment in Game-Based Learning: Foundations, Innovations, and Perspectives. New York: Springer. pp. 43-58.

Shute, V., Ventura, M., Bauer, M., \& Zapata-Rivera, D. (2009). Melding the power of serious games and embedded assessment to monitor and foster learning. Serious Games Mechanisms and Effects, 2, 295-321.

Simões, J., Redondo, R.D., \& Vilas, A.F. (2013). A social gamification framework for a K-6 learning platform. Computers in Human Behavior, 29(2), 345-353.

Strata-Etan Expert Group. (2002). Higher Education and Research for the ERA: Current Trends and Challenges for the Near Future. Brussels, Belgium: European Commission, DG Recherche.

Su, B., Bonk, C.J., Magjuka, R.J., Liu, X., \& Lee, S.H. (2005). The importance of interaction in web-based education: A program-level case study of online MBA courses. Journal of Interactive Online Learning, 4(1), 1-19.

Šumak, B., \& Šorgo, A. (2016). The acceptance and use of interactive whiteboards among teachers: Differences in UTAUT determinants between pre-and post-adopters. Computers in Human Behavior, 64, 602-620. 
Tam, M. (2000). Constructivism, instructional design, and technology: Implications for transforming distance learning. Educational Technology and Society, 3(2), 50-60.

Taylor, S.J., Bogdan, R., \& DeVault, M. (2015). Introduction to Qualitative Research Methods: A Guidebook and Resource. New Jersey: John Wiley and Sons Inc.

Toda, A.M., Do Carmo, R.S., Silva, A.L., \& Brancher, J.D. (2014). Project SIGMA-An Online Tool to Aid Students in Math Lessons with Gamification Concepts. Available from: http://www.jcc2014.ucm.cl/ jornadas/EVENTOS/SCCC\%202014/SCCC9.pdf. [Last Retrieved on 2018 Jul 14]. van Laar, E., van Deursen, A.J., van Dijk, J.A., \& de Haan, J. (2017). The relation between $21^{\text {st }}$-century skills and digital skills: A systematic literature review. Computers in Human Behavior, 72, 577-588.

Wood, L.C., \& Reiners T. (2012). Gamification in Logistics and Supply Chain Education: Extending Active Learning. Paper Presented at the IADIS 2012 International Conference on International Higher Education. Perth, Australia.

Zichermann, G., \& Cunningham, C. (2011). Gamification by Design: Implementing Game Mechanics in Web and Mobile Apps. Canada: O’Reilly Media. 